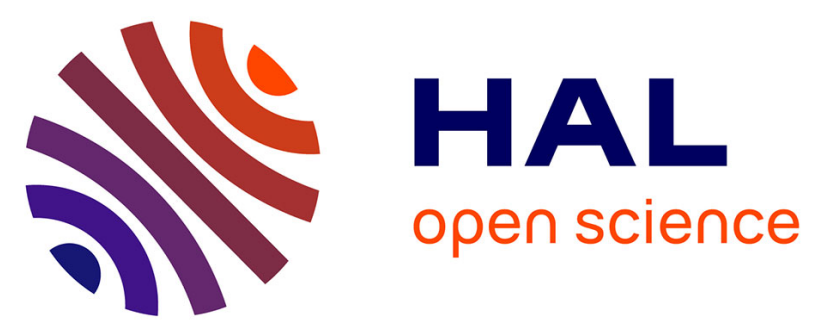

\title{
Is management with lamivudine always the appropriate choice for HBV patients with onco-hematologic diseases?
}

M. Christina Cox, Massimo Marignani, Barbara Veggia, Stefano Angeletti, Francesco Leone, Paola Cipriani, Sara Gallina, Gianfranco Delle Fave, M. Antonietta Aloe-Spiriti, Bruno Monarca

\section{To cite this version:}

M. Christina Cox, Massimo Marignani, Barbara Veggia, Stefano Angeletti, Francesco Leone, et al.. Is management with lamivudine always the appropriate choice for HBV patients with oncohematologic diseases?. Annals of Hematology, 2008, 88 (3), pp.283-284. 10.1007/s00277-008-0609-2 . hal-00486531

\section{HAL Id: hal-00486531 \\ https://hal.science/hal-00486531}

Submitted on 26 May 2010

HAL is a multi-disciplinary open access archive for the deposit and dissemination of scientific research documents, whether they are published or not. The documents may come from teaching and research institutions in France or abroad, or from public or private research centers.
L'archive ouverte pluridisciplinaire HAL, est destinée au dépôt et à la diffusion de documents scientifiques de niveau recherche, publiés ou non, émanant des établissements d'enseignement et de recherche français ou étrangers, des laboratoires publics ou privés. 


\title{
Is management with lamivudine always the appropriate choice for HBV patients with onco-hematologic diseases?
}

\author{
M. Christina Cox • Massimo Marignani • \\ Barbara Veggia • Stefano Angeletti • Francesco Leone • \\ Paola Cipriani • Sara Gallina • Gianfranco Delle Fave • \\ M. Antonietta Aloe-Spiriti • Bruno Monarca
}

Received: 21 August 2008 / Accepted: 3 September 2008 / Published online: 20 September 2008

(C) Springer-Verlag 2008

\section{Dear Editor,}

We read with interest the article by Yi-Fu H. et al. [1] about the effectiveness of Lamivudine (LAM) prophylaxis in preventing hepatitis B viral (HBV) reactivation in Rituximab containing regimens (so called immunochemotheraphy, ICT) for lymphoma and would like to make a contribution to this emerging topic. All patients diagnosed with Non-Hodgkin Lymphoma (NHL) from January 2005 to March 2008, at our Institution, were screened for HBV serology: HBsAg, anti-HBs, anti-HBc, $\mathrm{HBeAg}$, anti-HBe. Patients were also tested for HCV antibodies (HIV-positive patients were not included): 18 out of 159 patients (11.3\%) had serological signs of HBV exposure. 12 out of 159 (8.1\%) patients were HCV-infected. Seven out of $18 \mathrm{HBV}$ carriers were coinfected with $\mathrm{HCV}(38.8 \%)$. In 11 out of 18 patients (61\%), HBsAg were negative [2], anti-HBc (nine patients), anti-HBs (one patient, no history of previous vaccination), anti-HBc/anti-HBe/anti-HBs (one patient) being the only positive markers of previous HBV exposure.

Three patients were known to be affected by mild HBV chronic active hepatitis at the time of lymphoma diagnosis and were treated with LAM to contain the disease process

M. C. Cox $(\bowtie) \cdot$ B. Veggia $\cdot$ M. A. Aloe-Spiriti $\cdot$ B. Monarca Hematology, A.O. Sant'andrea, Universita' La Sapienza, via di Grottarossa 1034,

00189 Rome, Italy

e-mail: chrisscox@gmail.com

M. Marignani $\cdot$ S. Angeletti $\cdot$ S. Gallina $\cdot$ G. D. Fave Gastroenterology, A.O. Sant'andrea, Universita' La Sapienza, Rome, Italy

F. Leone $\cdot$ P. Cipriani

Microbiology, A.O. Sant'andrea, Universita' La Sapienza, Rome, Italy before and after ICT. The remaining four inactive HBsAg carriers and the $11 \mathrm{HBsAg-negative/antiHBc-positive}$ patients were started on LAM as a preemptive treatment to prevent possible disease reactivation [3].

Patients began treatment with LAM $100 \mathrm{mg}$ /day po on average 3-4 weeks before embarking on chemotherapy, after signing informed consent. All 159 patients were given R-CHOP or R-CHOP-like regimens [4]. LAM treatment was extended to 18 months after that the new indications from the dedicated commission of the Italian Study of the Liver became widely available in 2007 [3]. During and after ICT discontinuation, patients were tested every 2 months for HBsAg, quantitative-HBV-DNA, ALT, and AST. Median follow-up time was 7 months (range 3-43). Five of the seven HBsAg-positive patients $(71.4 \%)$ became HBV-DNA positive during follow-up at $25,18,18,10$, and 7 months after commencing LAM. In two patients, emergence of HBV-DNA positivity was associated with an increase of serum transaminases (up to five times the upper normal limit). In these five patients, AdefovirDipivoxyl, $10 \mathrm{mg} /$ day po, was combined with LAM, resulting in a disappearance of HBV-DNA and regression of the biochemical signs of hepatitis. None of these patients had to discontinue ICT because of HBV reactivation. No liver-related deaths occurred. None of the HBcAbpositive, anti-HBs-positive/HBsAg-negative patients (potential silent carriers) developed HBV reactivation during the period of observation. No side effect related either to LAM or ADV was registered. Four out of seven of these patients are now undergoing new treatments because of lymphoma progression.

The prevalence of $\mathrm{HBV}$ infection is high among patients diagnosed with NHL as compared to less than $2 \%$ of the Italian adult population [5]. Reactivation of HBV infection can present a serious threat to these patients and to the 
completion of their chemotherapeutic protocol. Thus, before proceeding to ICT, it is widely accepted that HBsAg active carriers should be treated, and preventative measures should be given to the silent carriers. In addition, HBsAgnegative or anti-HBc+patients (potential occult carriers) with onco-hematological malignancies can also develop severe hepatitis flare when treated with immunosuppressive regimens such as ICT. We, therefore, following the suggestions of the consensus conference [3], also administered LAM to our HBV-occult carriers. In our series, the incidence of reactivation in the HBsAg-positive cases (both active and inactive carriers) was high (71.4\%). Yu-FE et al. described a very low incidence of reactivation in HBsAgpositive, possibly due to the fact that in their series, patients were monitored by transaminase screening and as a result, the true incidence of virus reactivation might have been underestimated. Nevertheless, existing data on the effectiveness of LAM prophylaxis for patients treated with ICT can vary widely depending on the sample size.

In addition, we believe that it has to be taken into account that a substantial proportion of lymphoma patients will unfortunately suffer a relapse and will, therefore, require additional cycles of chemotherapy, prolonging their state of immunodepression. On the basis of our observations, we suggest LAM as a preemptive treatment in onco-hematologic HBsAg-positive patients with a high probability of cure after first line treatment and as a preventative measure in HBV occult carriers undergoing ICT. While new drugs, such as Entecavir [6], are more powerful and faster acting, they might be more useful when longer lasting or repeated treatments are required as they provide protection against the development of drug resistance. Whichever antiviral drug is administered, an extended follow-up term, for HBV reactivation, is recommended after ICT discontinuation. What is remarkable in our series is that $38.8 \%$ of HBV carriers were co-infected with $\mathrm{HCV}$. Since HCV and HBV carriers are supposed to be more prone to the development of lymphoproliferative diseases [7], it should not be ruled out that a double viral infection determines an even greater risk of lymphoma occurrence [8].

\section{References}

1. Yi-Fu H, Yu-Hong L, Feng-Hua W, Wen-Qi J, Rui-Hua X, Xiao-Fei $S$ et al (2008) The effectiveness of lamivudine in preventing hepatitis $\mathrm{B}$ viral reactivation in rituximab-containing regimen for lymphoma. Ann Hematol 87:481-485 doi:10.1007/ s00277-008-0454-3

2. Raimondo G, Navarra G, Mondello S, Costantino L, Colloredo G, Cucinotta E et al (2008) Occult hepatitis B virus in liver tissue of individuals without hepatic disease. J Hepatol 48:743-746. doi:10.1016/j.jhep.2008.01.023

3. Marzano A, Angelucci E, Andreone P, Brunetto M, Bruno R, Burra P et al (2007) Italian association for the study of the liver. Prophylaxis and treatment of hepatitis B in immunocompromised patients. Dig Liver Dis 39:397-408. doi:10.1016/j.dld.2006.12.017

4. Coiffier B, Lepage E, Briere J, Herbrecht R, Tilly H, Bouabdallah $\mathrm{R}$ et al (2002) CHOP chemotherapy plus rituximab compared with CHOP alone in elderly patients with diffuse large-B-cell lymphoma. N Engl J Med 346:280-282 doi:10.1056/NEJMoa011795

5. Da Villa G, Romanò L, Sepe A, Iorio R, Paribello N, Zappa A et al (2007) Impact of hepatitis B vaccination in a higly endemic area of south Italy and long-term duration of anti-HBs ancibody in two cohorts of vaccinated individuals. Vaccine 25:3133-3136 doi:10.1016/j.vaccine.2007.01.044

6. Lai C-L, Gane E, Liaw Y-F, Hsu C-W, Thongsawat S, Wang Y, Chen Y, Heathcote EJ, Rasenack J, Bzowej N, Naoumov NV, Di Bisceglie AM, Zeuzem S, Moon YM, Goodman Z, Chao G, Constance BF, Brown NA, Globe Study Group (2007) Telbivudine versus lamivudine in patients with chronic hepatitis B. N Engl J Med 357:25r 20

7. Gaeta GB, Stornaiuolo G, Precone DF, Lobello S, Chiaramonte M, Stroffolini $\mathrm{T}$ et al (2003) Epidemiological and clinical burden of chronic hepatitis B virus/hepatitis $\mathrm{C}$ virus infection. A multicenter Italian study. J Hepatol 39:1036-1041 doi:10.1016/S0168-8278 (03)00470-7

8. Chen MH, Hsiao LT, Chiou TJ, Liu JH, Gau JP, Teng HW et al (2008) High prevalence of occult hepatitis B virus infection in patients with B-cell non-Hodgkin's lymphoma. Ann Hematol 87:475-480 doi:10.1007/s00277-008-0469-9 